\title{
HYPOTHALAMUS-PITUITARY-TESTIS INTERACTION
}

\author{
P. FRANGHIMONT, S. GHARI AND A. DEMOULIN \\ Institute of Medicine, Radioimmunoassay Laboratory, \\ University of Liege, Belgium
}

The recent observation by Schally \& co-authors (1971) that the release of both $\mathrm{LH}$ and FSH is dependent upon the one 'releasing' hormone (LH-RH) has made the study of the hypothalamus-pituitary-testis axis much more complex. Furthermore, the normal maintenance of both spermatogenesis and testosterone secretion depends upon LH and FSH acting synergistically. It may, therefore, be surmised that there is no absolute specificity of gonadal steroids or other substances in the regulation of secretion of gonadotrophins.

Nevertheless, FSH and LH secretion appear to be dissociated in certain pathological conditions. When the Leydig cells are normal but the germinal epithelium has been damaged or destroyed, as after irradiation, certain viral infections, the administration of anti-fertility agents or in idiopathic infertility, the LH levels stay within the normal range whilst those for FSH are elevated (Franchimont, 1966, 1971, 1972; Paulsen et al., 1968; Rosen \& Weintraub, 1971; de Kretser et al., 1972; Leonard et al., 1972; van Thiel et al., 1972).

It is intended in this paper to examine the basal secretion of the gonadotrophins (mainly LH and to a lesser extent FSH) and the response in males to administration of steroids and LH-RH, and also the relationship between spermatogenesis and gonadotrophins.

\section{EFFECT OF ANDROGENS ON GONADOTROPHINS}

It is well accepted that the administration of testosterone to males is followed by a decrease in plasma LH levels. The effects on FSH, however, are controversial (Table 1). The reasons for the conflicting results obtained using virtually the same amounts of testosterone propionate (TP) are obscure. They may reflect the differences in the number of subjects studied, the route of administration, the action of sex hormone-binding protein and/or the particular radioimmunoassay used for FSH determination.

In general, TP administered in small doses preferentially suppresses serum LH as compared to serum FSH (Dufy-Barbe \& Franchimont, 1972; Swerdloff et al., 1972; Demoulin et al., 1973; Stewart-Bentley et al., 1974). For example, when five normal men were treated intramuscularly with $50 \mathrm{mg}$ TP daily for 5 days, plasma LH levels were lowered but FSH was not affected. The release of FSH and LH is unaffected by the administration of TP if $25 \mu \mathrm{g} \mathrm{LH}-\mathrm{RH}$ are given intravenously before treatment (see Text-fig. 1). These results are in agreement with those of von zur Muhlen \& Kobberling (1973) who have shown that four intramuscular injections of $100 \mathrm{mg}$ TP for 1 week significantly decreas- 
Table 1. The influence of testosterone and oestrone on gonadotrophin levels

\begin{tabular}{|c|c|c|c|c|c|}
\hline \multirow{2}{*}{ Reference } & \multirow{2}{*}{$\begin{array}{l}\text { Route of } \\
\text { administration }\end{array}$} & \multirow{2}{*}{ Dose/day } & \multirow{2}{*}{$\begin{array}{l}\text { No. of days } \\
\text { of treatment }\end{array}$} & \multicolumn{2}{|c|}{ Effects on: } \\
\hline & & & & FSH & $L H$ \\
\hline \multicolumn{6}{|l|}{ Testosterone } \\
\hline Franchimont (1966) & i.m. & $50 \mathrm{mg}$ & 1 & 0 & $\downarrow$ \\
\hline Franchimont (1970) & i.m. & $100 \mathrm{mg}$ & 1 & $\downarrow$ & \\
\hline Peterson et al. (1968) & i.m. & $25 \mathrm{mg}$ & 3 & 0 & \\
\hline Heller \& Heller (1970) & i.m. & $100 \mathrm{mg}$ & 5 & 0 & \\
\hline Burger et al. (1972) & i.m. & $100 \mathrm{mg}$ & 1 & $\downarrow$ & \\
\hline Lee et al. (1972) & i.m. & $5,12 \cdot 5,25 \mathrm{mg}$ & 3 & $\downarrow$ & \\
\hline Stewart-Bentley et al. (1974) & c.i. & $7 \mathrm{mg} *$ & 2 & 0 & \\
\hline & c.i. & $35 \mathrm{mg} *$ & 2 & $\downarrow$ & \\
\hline Sherins \& Loriaux (1973) & c.i. & $15 \mathrm{mg}$ & 4 & $\downarrow$ & \\
\hline \multirow{5}{*}{$\begin{array}{l}\text { Oestrone } \\
\text { Kulin \& Reiter (1973) } \\
\text { Legros et al. (1974) } \\
\text { Sherins \& Loriaux (1973) } \\
\text { Stewart-Bentley et al. (1974) }\end{array}$} & & & & & \\
\hline & Oral & 32 to $42 \mu \mathrm{g}$ & 7 & $\downarrow$ & $\mathbf{0}$ \\
\hline & Oral & $40 \mu \mathrm{g}$ & 4 & $i$ & 0 \\
\hline & $\begin{array}{l}\text { c.i. } \\
\text { c.i. }\end{array}$ & $\begin{array}{l}90 \mu \mathrm{g} \\
40 \mu \mathrm{g}^{*}\end{array}$ & $\begin{array}{l}4 \\
2\end{array}$ & $\begin{array}{l}\downarrow \\
0\end{array}$ & $\downarrow$ \\
\hline & c.i. & $200 \mu \mathrm{g} *$ & $\overline{2}$ & $\downarrow$ & 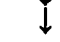 \\
\hline
\end{tabular}

i.m., Intramuscular; c.i., constant infusion; $\downarrow$, decrease.

* per $1.7 \mathrm{~m}^{2}$.
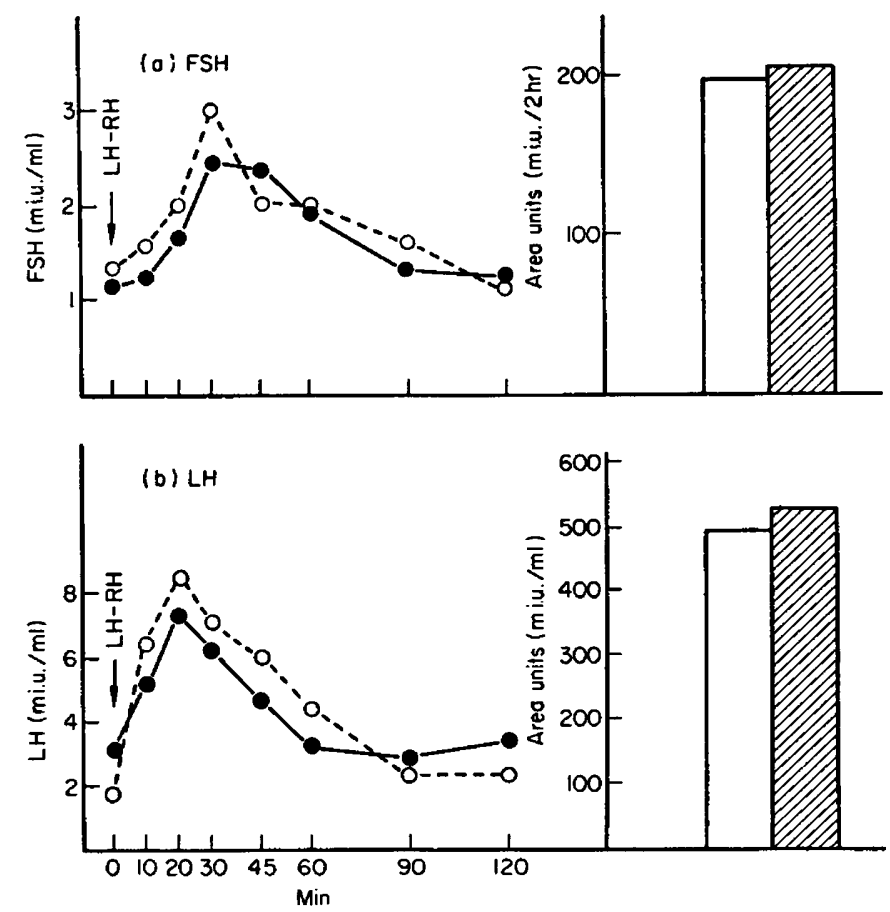

Text-Fig. 1. The effect of $25 \mu \mathrm{g} \mathrm{LH-RH} \mathrm{(arrow)} \mathrm{on} \mathrm{the} \mathrm{circulating} \mathrm{levels} \mathrm{of} \mathrm{(a)} \mathrm{FSH} \mathrm{and}$ (b) LH before ( $O$ and open columns) and after ( $O$ and hatched columns) the administration of $50 \mathrm{mg}$ testosterone propionate. The columns show the cumulative response correponding to the areas circumscribed by the serum FSH and LH curves during the first $2 \mathbf{~ h r}$ after LH-RH injection. 
ed the basal FSH and LH levels although the LH response to $100 \mu \mathrm{g} \mathrm{LH}-\mathrm{RH}$ was not diminished. On the contrary, the absolute quantity of LH liberated was increased.

Testosterone diminishes the normal LH levels and, at certain doses, the normal FSH levels, but it does not modify the response to LH-RH. The decrease of normal gonadotrophin levels is not related to a diminished pituitary gonadotrophin responsiveness to LH-RH or to a decreased gonadotrophin storage, but rather to an inability to release the hormones due to insufficient endogenous LH-RH stimulation. The evidence suggests, therefore, that testosterone acts essentially at the level of the hypothalamus. Kamberi \& McCann (1972) and Steinberger \& Chowdhury (1974) have shown in rats that testosterone regulates primarily the release of FSH rather than its synthesis. This action of testosterone may be due to the steroid itself or to one of its metabolites, such as $5 \alpha$-dihydrotestosterone (DHT). The role of this potent androgen in a feed-back mechanism has been investigated. The results obtained from studies in man are controversial. The constant infusion of a low dose of DHT ( $7 \mathrm{mg} /$ day $\left./ 1.7 \mathrm{~m}^{2}\right)$ significantly suppressed $\mathrm{LH}$ after $48 \mathrm{hr}$ but did not affect FSH (Stewart-Bentley et al., 1974). On the other hand, the constant infusion of $7.5 \mathrm{mg} \mathrm{DHT} /$ day for $96 \mathrm{hr}$ was without effect on either FSH or LH concentrations (Sherins \& Loriaux, 1973). In rats, when the total amount of DHT administered is lowered to $280 \mu \mathrm{g}$ for 2 days (Dufy-Barbe \& Franchimont, 1972; Demoulin et al., 1973) or to $500 \mu \mathrm{g}$ over 5 days (Swerdloff et al., 1972), the LH levels are reduced but FSH remains unaltered. Higher doses brought about a reduction in the levels of both FSH and LH.

The inhibitory effect of $5 \alpha$-androstane- $3 \alpha, 17 \beta$-diol on LH levels in castrated rats is considerably greater than that of testosterone and slightly more so than that of DHT. At doses lower than $560 \mu \mathrm{g}$ for 2 days androstanediol induces no modification of FSH levels (Demoulin et al., 1973).

The $5 \alpha$-reduction of testosterone is irreversible, so that any action DHT and $5 \alpha$-androstane- $3 \alpha, 17 \beta$-diol have on the hypophysis and hypothalamus must be due to that configuration. Furthermore, their A rings are saturated and cannot be aromatized into oestrogens. As testosterone could be converted into oestrogens (MacDonald et al., 1967; Baird et al., 1968; Loncope et al., 1969) and as the testis is also capable of producing oestrogens (Kelch et al., 1972), it was obviously of interest to study the effect of oestrogens on LH and FSH levels.

\section{EFFEGTS OF OESTROGENS ON GONADOTROPHINS}

The effects of oestrogens on gonadotrophin levels in men are not consistent. The administration of oestrogens at a dose rate corresponding to the mean daily production rate (30 to $40 \mu \mathrm{g}$ ) produced a decrease of FSH leve!s without altering LH levels (Kulin \& Reiter, 1973; Legros et al., 1974), whereas StewartBentley $e t$ al. (1974) observed a decrease in LH levels without modification of FSH using a constant infusion of oestradiol- $17 \beta\left(40 \mu \mathrm{g} / \mathrm{day} / 1.7 \mathrm{~m}^{2}\right)$ for 2 days (Table 1).

Larger doses of oestrogens lead to a rapid and marked decrease in the levels of both gonadotrophins (Peterson et al., 1968; Swerdloff \& Odell, 1968; Burger et al., 1972). In a recent experiment, seven young men were studied be- 
fore and after a 4-day course of ethinyloestradiol at a dose rate of $40 \mu \mathrm{g} / \mathrm{day}$. Blood samples were taken every $10 \mathrm{~min}$ for $5 \mathrm{hr}$ and the gonadotrophin response to $25 \mu \mathrm{g} \mathrm{LH}-\mathrm{RH}$ was determined the day before and on the last day of treatment. The mean FSH levels observed over $5 \mathrm{hr}$ were significantly decreased by the treatment (see Text-figs 2 and 3). The mean LH level after treatment was not statistically different from that found before the oestrogen was administered, although its pulsatile secretion, pulse amplitude and frequency were reduced so that less variation occurred during the sampling period (Textfig. 2).
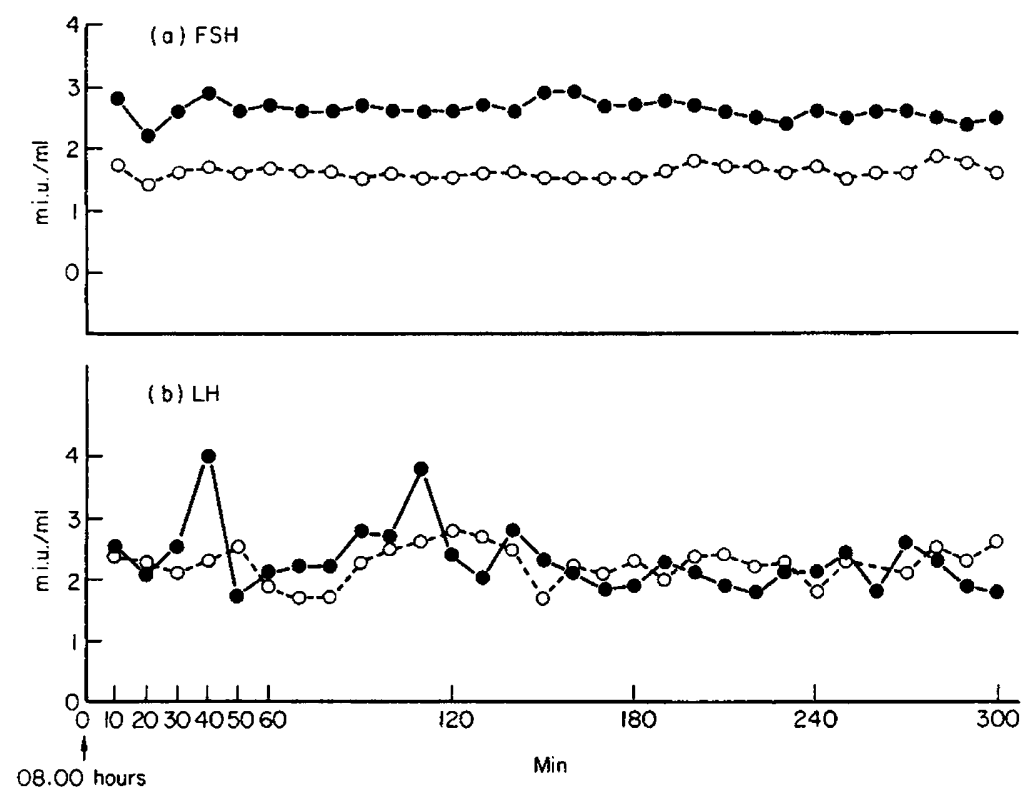

Text-Fig. 2. The effect of the daily administration of $40 \mu \mathrm{g}$ ethinyl oestradiol on the mean levels of (a) FSH and (b) LH measured before (O) and 4 days after (O) treatment.

The FSH and LH response to $25 \mu \mathrm{g} \mathrm{LH}-\mathrm{RH}$ given intravenously is significantly decreased after 4 days of treatment with $40 \mu \mathrm{g}$ ethinyloestradiol/day. This consistent inhibitory effect on the response to a submaximal dose of $\mathrm{LH}$ $\mathrm{RH}$ is in agreement with the results from intact adult male rats reported by Debeljuk et al. (1972). Similarly, Besser \& Mortimer (1974) have shown that oestrogen administration to normal men markedly reduced the LH and FSH response to a continuous infusion of LH-RH.

In brief, oestrogens suppress FSH levels below normal and at certain doses also reduce LH levels. Furthermore, they reduce the FSH and LH response to LH-RH. Oestrogens thus seem to act directly at the level of the pituitary on the synthesis and/or storage of the gonadotrophins.

In our hands, there appears to be a major difference in the action of pharmacological doses of TP and physiological doses of ethinyloestradiol. The former acts at the hypothalamic level without modifying the response to exogenous LH-RH, whilst the latter acts on the pituitary decreasing the FSH and LH quantities releasable by LH-RH. 
Santen (1974) has shown that oestradiol and testosterone have dissimilar effects on the episodic release of LH suggesting different mechanisms of action. Thus, oestradiol and testosterone produced similar suppressions of mean $\mathrm{LH}$ levels during the infusion period (approximately 20\%) and during the $6 \mathrm{hr}$ following infusion (approximately $21 \%$ ), but exerted an opposite effect on pulsatile LH secretion. During testosterone administration, the pulse frequency was significantly reduced although the amplitude was higher than during the control period. During oestradiol infusion, the pulse amplitude was lower than observed during the control period and the frequency was slightly reduced.
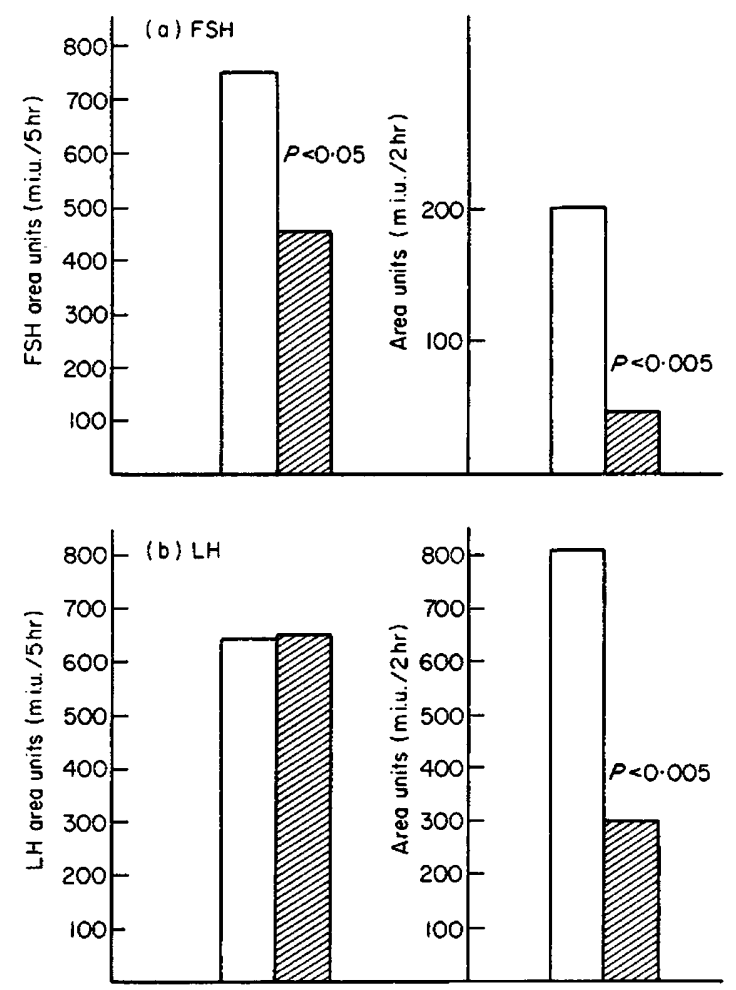

Texr-Fig. 3. The effect of ethinyloestradiol on serum levels of (a) FSH and (b) LH over a $5-\mathrm{hr}$ period (left-hand columns) and the effect of $25 \mu \mathrm{g} \mathrm{LH}-\mathrm{RH}$ (right-hand columns) before (open columns) and 4 days after (hatched columns) oestrogen treatment. The columns show the cumulative response corresponding to the mean areas circumscribed by the serum FSH and LH curves for (a) $5 \mathrm{hr}$, see Text-fig. 2; and (b) $2 \mathrm{hr}$ after the LH-RH injection.

\section{EFFEGT OF GYPROTERONE ACETATE ON GONADOTROPHINS}

The intramuscular injection of 100 and $300 \mu \mathrm{g}$ cyproterone acetate (a potent antiandrogen) decreased the basal FSH and LH levels (Franchimont, 1971). We have repeated these experiments, but with intravenous administration of $25 \mu \mathrm{g}$ LH-RH the day before and 4 days after the intramuscular injection of $100 \mathrm{mg}$ cyproterone acetate to five normal men. The LH response to LH-RH 
was higher 4 days after administration of the drug than before, whilst FSH release did not change (Text-fig. 4). When higher doses (100 $\mathrm{mg}$ and $300 \mathrm{mg}$ ) of cyproterone acetate were given orally for longer periods (12 days), the normal levels of FSH and LH diminished and so did their response to LH-RH.

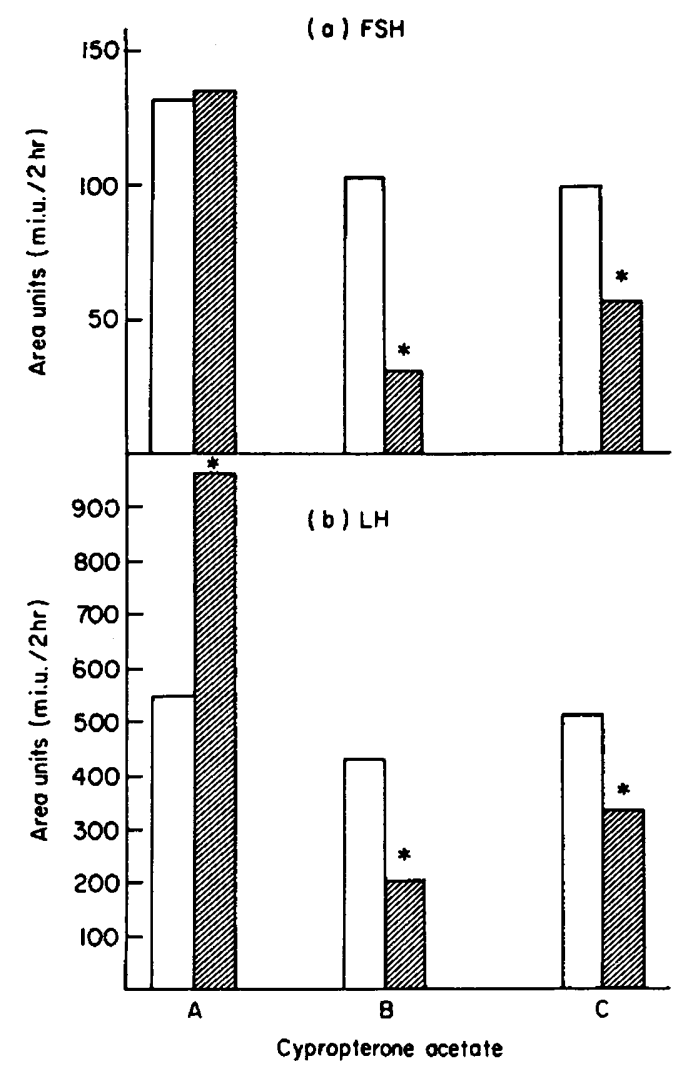

TexT-FIG. 4. The cumulative responses of (a) FSH and (b) LH levels to $25 \mu \mathrm{g} \mathrm{LH}-\mathrm{RH}$ before (open columns) and after (hatched columns) cyproterone acetate administration given as a single intramuscular injection of $100 \mathrm{mg}$ (A), or oral administration of $100 \mathrm{mg}$ (B) or $300 \mathrm{mg}$ (C) daily for 12 days. $* P<0.05$.

This difference in response to LH-RH could be interpreted as a result of prolonged deficiency of endogenous LH-RH which is involved in the synthesis of gonadotrophins (Redding et al., 1972). It might also be explained by a direct action of this larger dose on the pituitary synthesis and/or storage of gonadotrophins. The single dose of cyproterone acetate, like testosterone, acts at the hypothalamic level and inhibits the release of endogenous LH-RH without affecting synthesis and/or storage of the pituitary gonadotrophins.

EFFECT OF CLOMIPHENE GITRATE ON GONADOTROPHINS

It is well established (see review by Franchimont, 1971) that the administration of $200 \mathrm{mg}$ clomiphene citrate daily for 5 days causes a significant increase in the 
levels of FSH and LH. If LH-RH is given intravenously after clomiphene treatment, the increase in FSH and LH levels is even more pronounced than without pretreatment (Text-fig. 5). Kastin et al. (1970) have previously shown that LH-RH induces the release of LH and FSH in clomiphene-treated subjects, but they did not, however, investigate any altered responsiveness of the pituitary to the treatment.

On the basis of other reports (Bardin et al., 1967; Baier \& Taubert, 1969; Marshall et al., 1972) and our own results, clomiphene citrate may be considered to act at the hypothalamic level, increasing the endogenous LH-RH and consequently the synthesis and storage of pituitary gonadotrophins.
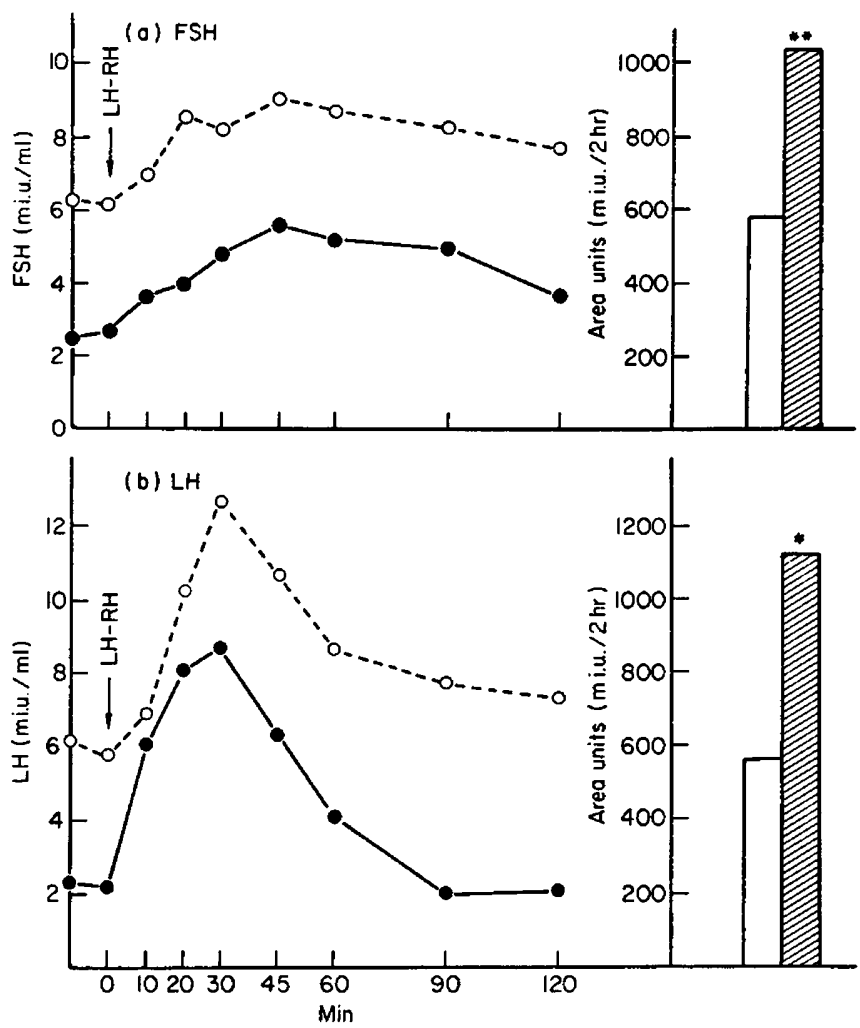

TEXT-FIG. 5. The response of (a) FSH and (b) LH levels to $25 \mu \mathrm{g} \mathrm{LH-RH}$ intravenously before (and open columns) and 5 days after ( $O$ and hatched columns) the daily administration of $200 \mathrm{mg}$ clomiphene citrate. The cumulative response (columns) was calculated as described in the legend of Text-fig. $1 . * P<0.01 ; * * P<0.05$.

\section{RELATIONSHIP BETWEEN FSH LEVELS AND SPERMATOGENESIS}

A study of idiopathic infertility was and still is an informative means of a better understanding of the relationship between spermatogenesis and FSH secretion.

There are three different views regarding this relationship. (1) There is a specific stage( $\mathrm{s}$ ) in the process of spermatogenesis involved in testicular feedback on FSH secretion; at the stage of spermatid formation (Franchimont, 1972) or at the point of maturation of the spermatozoa (Johnsen, 1970). (2) There 
is no correlation between FSH levels and any specific cell stage and the germinal cells do not play any role, direct or indirect, in the feedback regulation of FSH secretion (Paulsen et al., 1972; de Kretser et al., 1974). (3) There is no feedback signal at any specific stage of spermatogenesis but an inverse correlation exists between FSH levels and the severity of the reduction of germinal cells from spermatogonia to late spermatids (de Kretser et al., 1974).

We have analysed the correlations between FSH and LH levels, FSH and $\mathrm{LH}$ response to $\mathrm{LH}-\mathrm{RH}$ injection, sperm count, stage of spermatogenesis and prolactin levels.

\section{Correlation between sperm count and FSH and LH levels}

In cases of azoospermia due to abnormal spermatogenesis, FSH levels are often greater than normal, indicating that the primary lesion is at the germinal epithelium and that the pituitary responds to this deficiency by increasing its FSH secretion. Although LH and testosterone levels are often normal there is a significant incidence of abnormality even in patients thought to have only isolated defects in spermatogenesis (de Kretser et al., 1972). In eighty-five cases of oligospermia there was no correlation between serum FSH and LH levels and sperm count. This result confirmed those previously reported (de Kretser et al., 1972; Franchimont, 1972; Paulsen et al., 1972). Nevertheless, an absence of correlation has not been a universal finding. Rosen \& Weintraub (1971) found an inverse correlation between sperm count and serum FSH concentration in oligospermic subjects. Mauss \& Borsch (1973) also showed an inverse relationship between the logarithm of the sperm count and the urinary excretion of FSH.

\section{Correlation between basal FSH levels and stage of spermatogenesis}

In eighty-five cases of oligospermia and azoospermia, we have found a direct correlation ( $r=0.79$; Text-fig. 6$)$ between the basal FSH levels and the stage of spermatogenesis as defined earlier (Franchimont, 1972).

It must be pointed out that FSH levels are always abnormally high during stage 0 to 4 when spermatids have not yet been formed. But the highest levels of FSH are found when spermatogenesis has been arrested in the earlier stages or is completely absent.

\section{Correlation between basal FSH levels and response to $\mathrm{LH}-\mathrm{RH}$}

An intravenous injection of $25 \mu \mathrm{g} \mathrm{LH}-\mathrm{RH}$ was given to each of twenty-eight subjects and the response was evaluated by the maximum FSH levels attained during the following $2 \mathrm{hr}$ or by the cumulative response, as described earlier. A close correlation was found between the two parameters and the basal levels of FSH. Thus all the patients with high basal FSH levels showed higher responses to LH-RH than did normal subjects. Similarly, patients with normal FSH levels displayed a normal response to LH-RH, except for two subjects in whom the response was abnormally high, although examination of biopsy material showed that these patients were at stages 5 and 6 . This discrepancy could be due to the spontaneous fluctuations of FSH observed in gonadal diseases (Root et al., 1972). 


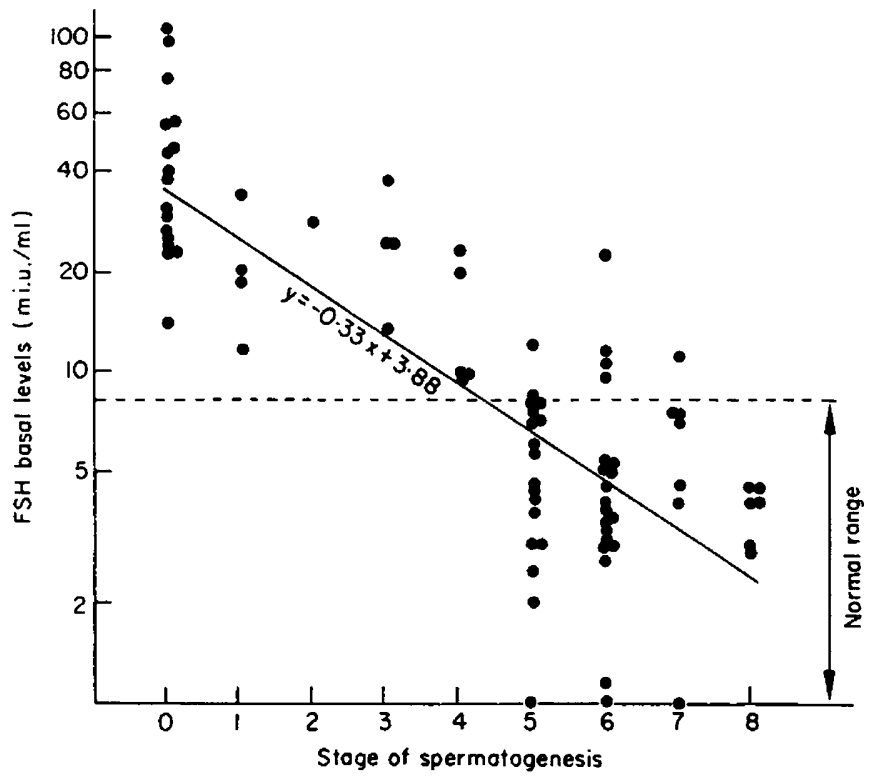

TexT-FIG. 6. Correlation between the stage of spermatogenesis and basal FSH levels $(r=0.79 ; P<0.0005)$. The stages of spermatogenesis have been described previously (Franchimont et al., 1972): stage $0=$ all the seminiferous tubules are hyalinized; stage $1=$ Sertoli cells are the only constituents of the seminiferous tubules; stage $2=$ some spermatogonia are present in addition to Sertoli cells; stage $3=$ Sertoli cells, spermatogonia and a few scattered primary spermatocytes are seen; stage $4=$ this stage corresponds to spermatogenic arrest. Great numbers of primary spermatocytes are seen forming a continuous layer around the tubular lumen; stage $5=$ some spermatids are now present but spermatozoa are entirely absent; stage $6=$ maturation is complete with a normal number of spermatids and a few spermatozoa; stage $7=$ all stages are represented in suitable proportions but the number of germ cells is low: the seminiferous epithelium consists of only three or four cell layers; stage $8=$ spermatogenesis is complete.

\section{Correlation between $\mathrm{LH}$ and spermatogenesis}

A correlation between basal LH levels and the LH response to $25 \mu \mathrm{g} \mathrm{LH}$ RH was found in the twenty-eight cases studied. As previously described (Franchimont et al., 1972), there is no evident relationship between LH levels and $\mathrm{LH}$ response to $\mathrm{LH}-\mathrm{RH}$, on the one hand, and the stage of spermatogenesis on the other.

\section{Correlation between prolactin and spermatogenesis}

Fifteen subjects were injected with $200 \mu \mathrm{g}$ TRH and prolactin was assayed in the sera collected 20 and 60 min later. In all cases, prolactin reached its maximum level in the range of \pm 2 standard deviations compared with the mean of the normal maximum response: $43.4 \mathrm{ng} \pm 10 \cdot 1$ ( \pm S.D.). From these observations, we have concluded that the basal level of the gonadotrophins is an index of pituitary reserve releasable by a constant amount of exogenous LH-RH.

By examination of the basal FSH levels and the FSH response to LH-RH, azoospermic and oligospermic patients may be divided into two groups, those with normal FSH levels and a normal response to LH-RH and those with 
high FSH levels and an exaggerated response to LH-RH. All the patients in which spermatogenesis had not proceeded to the stage of spermatid formation fell into this last category. This confirms our earlier observations (Franchimont et al., 1972) that there is an inverse correlation between basal FSH levels and FSH response to LH-RH on the one hand and the stage of spermatogenesis on the other. Thus the poorer the basal germinal cell population, the higher are the levels of FSH and the response to LH-RH.

To interpret the consistently high FSH levels and the response to LH-RH when spermatids are absent, one may postulate that the maturation of spermatids induces or permits the formation of a factor controlling FSH secretion. Alternatively, spermatids could have no specific function with regard to FSH regulation and reflect only a severe depression of the basal germinal cell population resulting in increased FSH levels.

There is no correlation between basal LH levels and LH response to LH-RH on the one hand and the defect in spermatogenesis judged by sperm count and analysis of testicular biopsy on the other.

The prolactin release induced by LH-RH was normal in the azoospermic and oligospermic cases studied.

\section{'INHIBIN'}

There is substantial evidence for the presence of a substance produced by the testis that selectively inhibits the secretion of FSH. This substance was first suspected by McGullagh in 1932. More recently, Setchell \& Sirinathsinghji (1972) have reported on the antigonadotrophic activity of a thermolabile substance from the testis fluid of the ram. In the same year, we showed that the injection of human seminal plasma decreased FSH levels in castrated male rats (Franchimont, 1972).

Lee et al. (1974) have shown a selective suppression of plasma FSH levels by essentially testosterone-free extracts of bovine testes. Hodgen et al. (1974), however, have reported a decrease in LH levels, without modification in plasma FSH concentration, in castrated rats injected with adult testis homogenate. The observed effect was not due to testosterone in the homogenate and was not produced by the epididymis.

We have extended our own investigations on the existence, nature and specificity of inhibitory action of this possible 'inhibin' in the seminal plasma of bull and man.

\section{Extraction of semen}

Bull or human semen was centrifuged for $15 \mathrm{~min}$ at $2200 \mathrm{~g}$ to separate the spermatozoa from the seminal plasma. Protein was precipitated by the addition of absolute ethanol to a concentration of $86 \%$. The precipitate was recovered by centrifugation at $4^{\circ} \mathrm{C}$, dissolved in distilled water and freeze-dried. This fraction is referred to as 'crude material'. The supernatant containing steroids was first extracted with 2 vols chloroform:ether $(1: 1, \mathrm{v} / \mathrm{v})$, and then with 2 vols diethylether. The ether-soluble fraction was recovered and used for steroid analysis; no inhibition of either FSH or LH levels was found when castrated male rats were treated with this fraction. 
The crude material $\left(300 \mathrm{mg}\right.$ ) was subjected to gel filtration at $4^{\circ} \mathrm{C}$ on Sephadex G $100(90 \times 2.5 \mathrm{~cm})$ using either $0.05 \mathrm{~m}$-sodium acetate buffer, $\mathrm{pH} 4$, or $0.05 \mathrm{M}$-phosphate buffer, $\mathrm{pH} 7.4$. Fractions of $2.5 \mathrm{ml}$ were collected.

The protein content of the samples was estimated spectrophotometrically by absorption at $280 \mathrm{~nm}$ and by the biuret method as described by Gornall et al. (1949).

When 'crude material' from bull seminal plasma is applied to a Sephadex G 100 column at an alkaline $\mathrm{pH}$, the elution profile shows two peaks-the first, an unretarded distinct peak (P I) and the second, a less-well defined peak (P II). At acidic $\mathrm{pH}$, there is a distinct separation of the two peaks (Ac I and Ac II); Ac I is eluted in the void volume, whereas Ac II is eluted in the second void volume (Text-fig. 7).

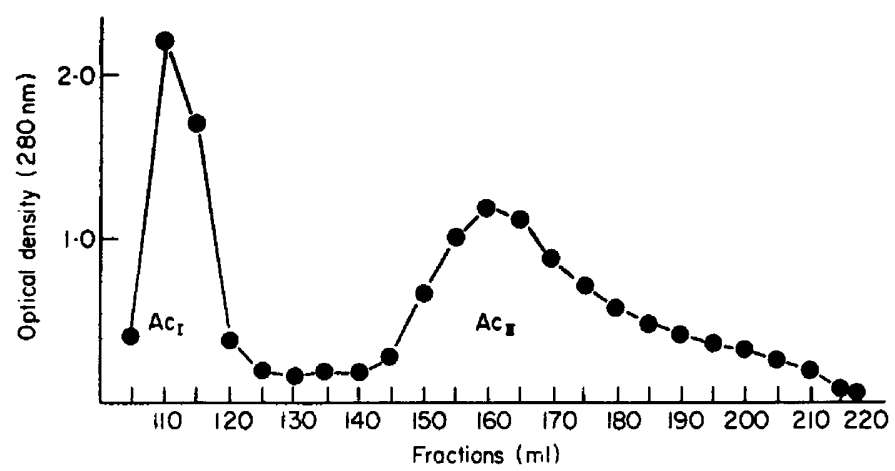

TEXT-Fig. 7. Elution profile of 'crude material' from bull seminal plasma protein fractions on Sephadex G 100. Elution buffer, 0.05 M-sodium acetate, pH 4.0.

\section{Evaluation of biological activity}

The ability of the different fractions to inhibit circulating levels of FSH and LH was determined in castrated adult male rats weighing between 180 and $200 \mathrm{~g}$. Fourteen days after castration, animals were injected intraperitoneally with buffered saline (control) or with the samples. The total dose was administered in four injections at $12 \mathrm{hr}$ intervals. The animals were bled and the FSH and LH concentrations determined $4 \mathrm{hr}$ after the last injection. In five experiments performed with five different batches of bull seminal plasma, $500 \mu \mathrm{g}$ Ac I produced slight but non-significant decreases in FSH and LH basal levels. Fraction AC II, however, at a dose of $200 \mu \mathrm{g} / \mathrm{rat}$, induced a significant decrease in FSH levels; the reduction in LH levels was inconsistent and never significant (Text-fig. 8).

To ascertain the polypeptide nature of the substance isolated by gel filtration at $\mathrm{pH} \mathrm{7.5,} \mathrm{it} \mathrm{was} \mathrm{subjected} \mathrm{to} \mathrm{pepsin} \mathrm{digestion} \mathrm{in} \mathrm{glycine-HGl} \mathrm{buffer} \mathrm{(} \mathrm{pH} 2)$ $(50: 1, \mathrm{v} / \mathrm{v})$ at $37^{\circ} \mathrm{C}$ for $18 \mathrm{hr}$ and administered to rats as above. The pepsin digestion destroyed the inhibitory ability of P II (Table 2).

The content of steroids, testosterone, progesterone and oestradiol-17 $\beta$ in the material collected in the second peak (AC II or P II) was investigated by radioimmunoassay. None was found. 


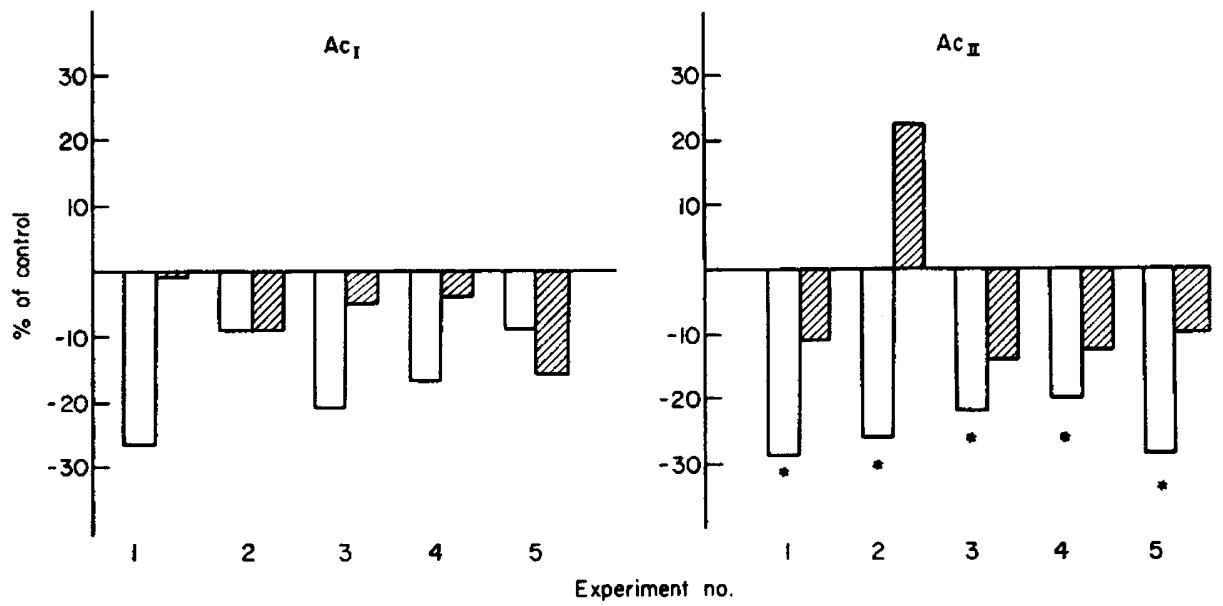

TexT-FIG. 8. The effect of the first acidic fraction (Ac I, $500 \mu \mathrm{g} / \mathrm{rat}$ ) and the second acidic fraction (Ac II, $200 \mu \mathrm{g} / \mathrm{rat}$ ) from gel filtration of bull seminal plasma expressed in $\%$ compared with control animals (0) on FSH (open columns) and LH (hatched columns) levels in castrated rats in five experiments. $* P<0.05$.
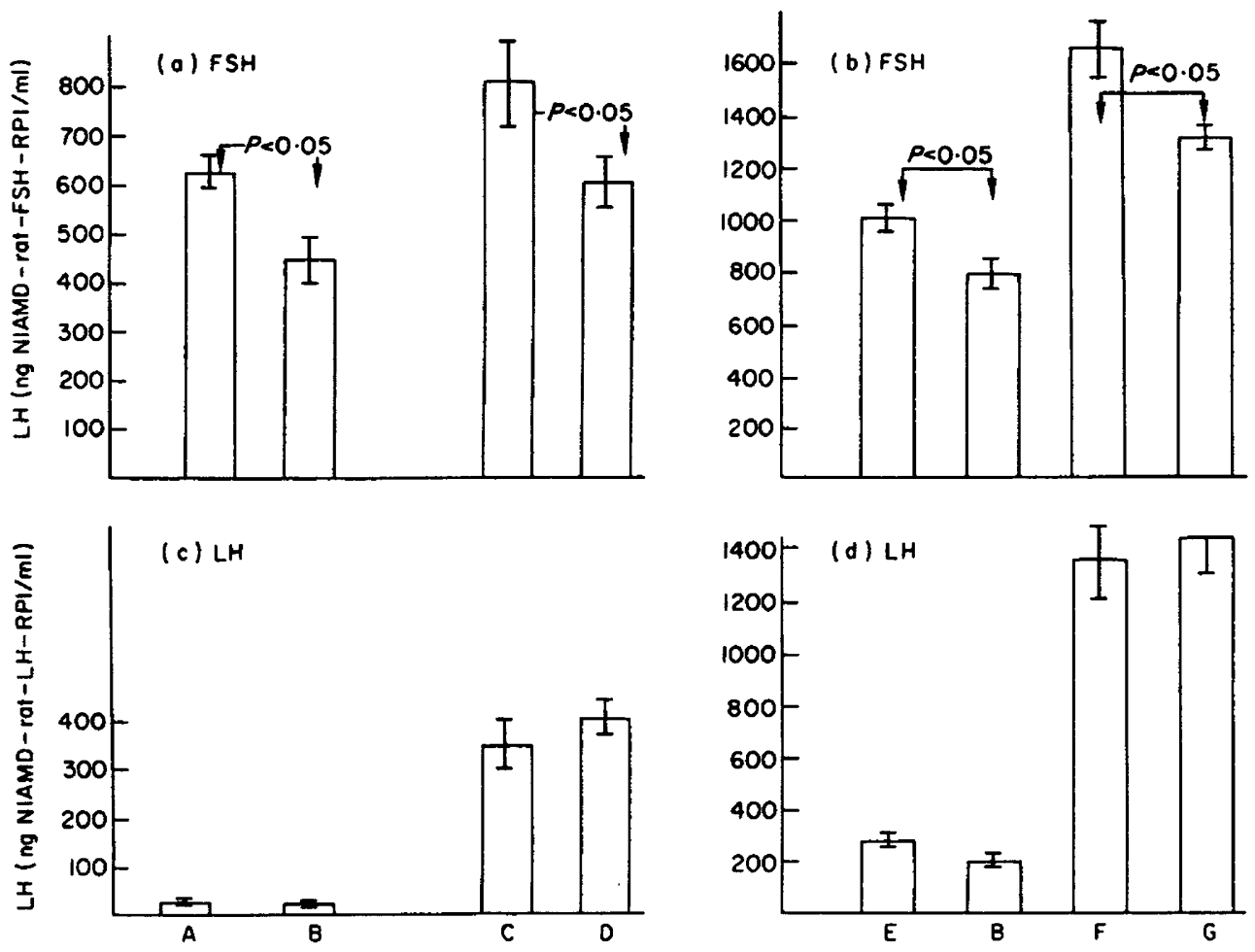

TEXT-FIG. 9. The effect in intact $(a, c)$ and castrated $(b, d)$ rats of intraperitoneal injection of $200 \mu \mathrm{g}$ AC II from bull seminal plasma on basal FSH (a,b) and LH (c,d) levels, and on the response to $5 \mu \mathrm{g} \mathrm{LH}-\mathrm{RH}$ or $7.5 \mu \mathrm{g} \mathrm{LH}-\mathrm{RH}$ given intravenously. Vertical bars represent \pm 1 S.E. A, intact control; B, $200 \mu \mathrm{g} \mathrm{AC} \mathrm{II/rat;} \mathrm{C,} 5 \mu \mathrm{g}$ LH-RH; D, $200 \mu \mathrm{g}$ AC II +5 $\mu \mathrm{g} \mathrm{LH-RH/rat;} \mathrm{E,} \mathrm{castrated} \mathrm{control;} \mathrm{F,} \mathrm{7.5} \mu \mathrm{g} \mathrm{LH}-\mathrm{RH} ; \mathrm{G}, 200 \mu \mathrm{g} \mathrm{AC} \mathrm{II+}$ $7 \cdot 5 \mu \mathrm{g}$ LH-RH/rat. 
Table 2. Effect of pepsin digestion on the biological activity of PII (see text)

\begin{tabular}{|c|c|c|c|c|}
\hline \multirow{2}{*}{ Treatment } & \multirow{2}{*}{$\begin{array}{c}\text { No. of } \\
\text { tests }\end{array}$} & \multicolumn{2}{|c|}{$F S H(n g / m l)$} & $L H(n g / m l)$ \\
\hline & & Mean $\pm S . D$. & $\%$ & Mean \pm S.D. $\%$ \\
\hline \multirow{2}{*}{$\begin{array}{l}\text { None (controls) } \\
200 \mu \mathrm{g} \text { PII } \\
200 \mu \mathrm{g} \text { PIII } \\
\text { digested by pepsin }\end{array}$} & $\begin{array}{l}6 \\
6\end{array}$ & $\begin{array}{c}1426 \pm 83 \cdot 1 \\
952 \cdot 5 \pm 98 \cdot 9 *\end{array}$ & $\begin{array}{r}100 \\
67\end{array}$ & $\begin{array}{cc}299 \cdot 3 \pm 83 & 100 \\
338 \pm 51 \cdot 2 \dagger & 111\end{array}$ \\
\hline & 6 & $1297 \pm 205 \dagger$ & 91 & $275 \pm 157.5 \dagger 92$ \\
\hline
\end{tabular}

* $P<0.001$ compared with the control values.

$\dagger$ Not significantly different from controls.

\section{Action of AC II on pituitary response to $L H-R H$}

Fourteen days after castration, animals were treated with $200 \mu \mathrm{g}$ AC II injected intraperitoneally as described earlier. One hour after the last injection, 5 or $7.5 \mu \mathrm{g} \mathrm{LH}-\mathrm{RH}$ dissolved in $0.5 \mathrm{ml}$ of $0.9 \% \mathrm{NaCl}$ were administered through

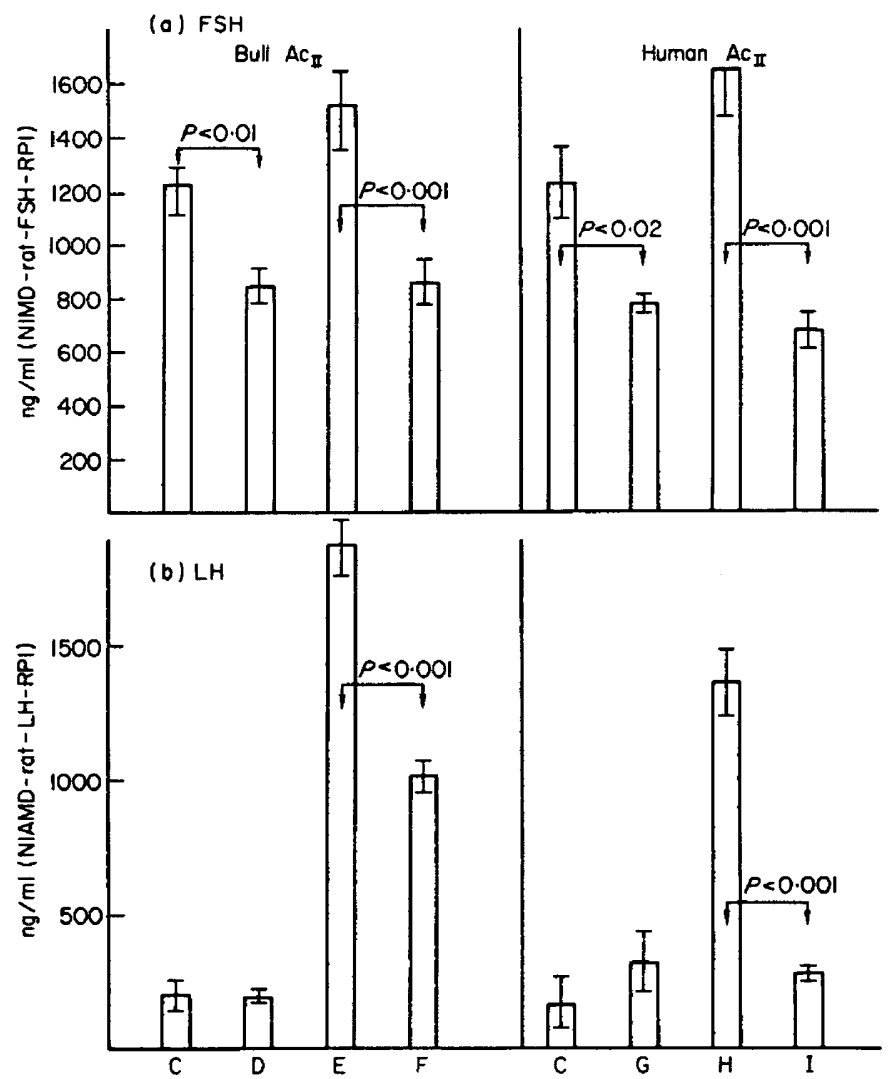

TexT-FIG. 10. The effect of $200 \mu \mathrm{g}$ bull AC II, or $1000 \mu \mathrm{g}$ human AC II injected intravenously on basal levels of (a) FSH and (b) LH in castrated rats treated in various ways. C, castrated controls; D, $200 \mu \mathrm{g}$ bull AC II ; E, $5 \mu \mathrm{g} \mathrm{LH-RH;} \mathrm{F,} 200 \mu \mathrm{g}$ bull AC II + $5 \mu \mathrm{g} \mathrm{LH}-$ RH; G, $1000 \mu \mathrm{g}$ human AC II; H, 7.5 $\mu \mathrm{g}$ LH-RH; I, $1000 \mu \mathrm{g}$ human AC JI $+7.5 \mu \mathrm{g}$ LH-RH. 
the tail vein, and the animals were killed 30 min later. Normal male rats were also treated in a similar manner.

In normal and castrated rats, $200 \mu \mathrm{g}$ AG II from bull seminal plasma decreased the FSH basal levels but did not alter LH levels. When LH-RH was injected, FSH and LH levels significantly increased. The pretreatment of rats with AC II diminished the response of FSH to LH-RH without affecting the LH response (Text-figs 9a and $9 \mathrm{~b}$ ).

In a different experiment, AC II was injected intravenously $1 \mathrm{hr}$ before the administration of LH-RH. The animals were killed $30 \mathrm{~min}$ later and again, a significant decrease in basal FSH levels was observed. The AC II fractions from bull as well as human seminal plasma, at dose levels of $200 \mu \mathrm{g}$ and $1000 \mu \mathrm{g}$, respectively, were capable of diminishing the increase in FSH and LH levels induced by LH-RH (Text-fig. 10).

From the above observations, we may draw the following conclusions. In human and bull seminal plasma there is a substance(s) which selectively decreases basal FSH levels. This substance appears to be protein in nature. Injected intraperitoneally, this substance decreases the FSH response to LH-RH, whilst injected intravenously, it produces a decrease in the response of both FSH and LH to LH-RH. Why the route of administration changes the nature of response is not yet clear.

\section{REFERENGES}

Bater, H. \& TAUBERT, H.D. (1969) Effect of clomiphene upon plasma FSH activity and hypothalamic FSH-RF content in ovariectomised oestrogen progesterone blocked rats. Endocrinology 84, 946949.

Baird, D., Horton, R., Langcope, C. \& TAit, J.F. (1968) Steroid pre-hormones. Perspect. Biol. Med. $1,384-421$.

Bardin, W.G., Ross, G.T. \& LipseTt, M.B. (1967) Site of action of clomiphene citrate in men: a study of the pituitary-Leydig cell axis. F. clin. Endocr. Metab. 27, 1558-1564.

Besser, G.M. \& Mortimer, C.H. (1974) Hypothalamic regulatory hormones: a review. F. clin. Path. 27, 173-184.

BURger, H.G., BAKER, H.W.G., Hudson, B. \& TAFT, H.P. (1972) Gonadotropic and gonadal function in the normal adult male. In Gonadotropins, pp. 569-592. Eds. B. B. Saxena, C. G. Beling and H. M. Gandy. Wiley Interscience, New York.

Debeljux, L., Arimura, A. \& Schally, A.V. (1972) Studies on the pituitary responsiveness to luteinizing hormone releasing hormone (LH-RH) in intact male rats of different ages. Endocrinology 90, 585-588.

de Kretser, D.M., Burger, H.G., Fortune, D., Hudson, B., Long, A.R., Paulsen, G.A. \& Taft, H.P. (1972) Hormonal histological and chromosomal studies in adult males with testicular disorders. F. clin. Endocr. Metab. 35, 392-401.

DE KRETSER, D.M., BuRGer, H.G. \& Hudson, B. (1974) Relationship between serum FSH levels and germinal cells in males with infertility. F. clin. Endocr. Metab. 38, 787-793.

Demoulin, A., Thieblot, P. \& Franchimont, P. (1973) Influence de differentes steroïdes et de la prostaglandins $\mathrm{E}_{1}$ sur le taux des gonadotrophines sériques chez le rat male castré. C. r. Séanc. Soc. Biol. $167,1684-1687$.

Dufy-Barbe, L. \& Franchimont, P. (1972) Influence des differentes steroïdes gonadiques sur le taux de la FSH et de la LH chez le rat castré. C. r. Séanc. Soc. Biol. 166, 960-964.

Franchimont, P. (1966) Le dosage des hormones hypophysaires somatotrope et son application en clinique. Thesis Arscia, Bruxelles et Maloine, Paris.

FRANChIMONT, P. (1970) Application of radioimmunoassay of gonadotrophins in clinical research. In Reproductive Endocrinology, pp. 20-25. Ed. W. J. Irvine. Livingstone, Edinburgh.

Franchimont, P. (1971) Secretion Normale et Pathologique de la Somatotrophine et des Gonadotrophines Humaines. Masson, Paris.

Franchimont, P. (1972) Human gonadotrophin secretion J. R. Coll. Physicians, Lond. 6, 283-298. 
Franchimont, P., Millet, D., Vendrely, E., Letawe, J., Legros, J.J. \& Netter, A. (1972) Relationship between spermatogenesis and serum gonadotrophin levels in azoospermia and oligospermia. 7. clin. Endocr. Metab. 34, 1003-1008.

Gornall, A.G., Bardawill, C.J. \& David, M.M. (1949) Determination of serum proteins by means of the biuret reaction. J. biol. Chem. 177, 751-766.

Heller, G.V. \& Heller, G.G. (1970) Quantitation of normal and abnormal germinal cells following administration of clomiphene citrate in normal men. F. clin. Endocr. Metab. 30, $196-207$.

Hodgen, G.D., Nixon, W.E. \& TURNer, C.K. (1974) Suppression of serum gonadotrophins in castrated rats by testis homogenates. Int. Res. Commun. Syst. 2, 1233.

JoHNSEN, S.G. (1970) Investigations into the feedback mechanism between spermatogenesis and gonadotrophin level in man. In The Human Testis, pp. 231-248. Eds. E. Rosemberg and C. A. Paulsen. Plenum Press, New York.

Kamberi, I.A. \& MaCanN, S.M. (1972) Effects of implants of testosterone in the median eminence and pituitary on FSH secretion. Neuroendocrinology 9, 20-29.

Kastin, A.J., Schally, A.V., Gual, G., Midgley, A.R., Miller, M.G. \& Flores, F. (1970) Increased release of LH after administration of LH-RH to men pretreated with clomiphene. 7 . clin. Endocr. Metab. 31, 689-692.

Kelch, R.P., Jenner, M.R., Weinstein, R., Kaplan, S.L. \& Grumbach, M.M. (1972) Estradiol and testosterone secretion by human semen and canine testis in males with hypergonadism and male pseudohermaphrodite with the feminizing testes syndrome. 7. clin. Invest. 51, 824-830.

Kulin, H.E. \& REITER, E.O. (1973) Gonadotrophin suppression by low dose oestrogen in man: evidence for differential effects upon FSH and LH. F. clin. Endocr. Metab. 35, 836-839.

Lee, P.A., JAffe, R.B., Midgley, A.R., Kohen, F. \& Niswender, G.D. (1972) Regulation of human gonadotrophin. VIII. Suppression of serum LH and FSH in adult males following exogenous testosterone administration. F. clin. Endocr. Metab. 35, 636-641.

LeE, V.W.K., Keogh, E.J., DE KRETser, D.M. \& Hudson, B. (1974) Selective suppression of FSH by testis extracts. Int. Res. Commun. Syst. 2, 1406.

Legros, J.J., Demoulin, A., Burger, H.G. \& Franchimont, P. (1974) Influence d'une dosage faible d'ethinyl oestradiol sur la liberation pulsatile des gonadotrophins et sur leur liberation hypophysaire sous l'influence du LH-RH chez l'homme normal. C. r. Séanc. Soc. Biol. (in press).

Leonard, J.M., Leach, R.B., Couture, M. \& Paulsen, C.A. (1972) Plasma and urinary follicle stimulating hormone levels in oligosprmia. F. clin. Endocr. Metab. 34, 209-214.

Longcope, C., Kato, T. \& Horton, R. (1969) Conversion of blood androgens to estrogens in normal and adult men and women. $\mathcal{F}$. clin. Invest. 48, 2191-2201.

MacDonatd, P.G., Rombaut, R.P. \& Sirteri, P.K. (1967) Plasma precursors of estrogen. I. Extent of conversion of $\Delta^{4}$-androstenedione to estrone in normal males and non-pregnant normal, castrate and adrenalectomised females. F. clin. Endocr. Metab. 27, 1103-1111.

MaCullaGH, D.R. (1932) Dual endocrine activity of the testis. Science, N.Y. 76, 19.

Marshall, J.C., Harsoulis, P., Anderson, D.C., McNeilly, A.S., Besser, G.M. \& Hall, R. (1972) Isolated pituitary gonadotrophin deficiency and gonadotrophin secretion after synthetic luteinizing hormone and follicle-stimulating hormone-releasing hormone. Br. med. F. i, 643-645.

Mauss, J. \& BoRsch, G. (1973) Immunochemical assay of follicle stimulating and luteinising hormone in the unconcentrated urine of sub or infertile males. Acta endocr., Copenh. 74, 631-641.

Paulsen, G.A., Gordon, D.L., Carpenter, R.W., Gandy, H.M. \& Drugker, W.D. (1968) Klinefelter's syndrome and its variants: a hormonal and chromosomal study. Recent Prog. Horm. Res. 24, 321-353.

Paulsen, G.A., Leonard, J.M., de Kretser, D. M. \& Leach, R.B. (1972) Interrelationship between spermatogenesis and follicle stimulating hormone levels. In Gonadotrophins, pp. 628-639. Eds. B. B. Saxena, C. G. Beling and H. M. Gandy. Wiley Interscience, New York.

Peterson, N.T., Midgley, A.R. \& Jafre, R.B. (1968) Regulation of human gonadotrophins. III. Luteinising hormone and follicle-stimulating hormone in sera from adult males. $\mathbf{f}$. clin. Endocr. Metab. 28, 1473-1478.

Redding, T.W., Schally, A.V., Arimura, A. \& Matsuo, H. (1972) Stimulation of release and synthesis of luteinising hormone (LH) and follicle stimulating hormone (FSH) in tissue cultures of rat pituitaries in response to natural and synthetic $\mathrm{LH}$ and FSH releasing hormone. Endocrinology 90, 764-770.

Root, A., de Cherney, A., Russ, D., Duckett, G., Garcla, G.R. \& Wallagh, E. (1972) Episodic secretion of luteinising and follicle stimulating hormones in agonadal and hypogonadal adolescents and adults. 7. clin. Endocr. Metab. 35, 700-704.

Rosen, S.W. \& WeINTRAub, B.D. (1971) Monotropic increase of serum FSH correlated with low sperm count in young men with idiopathic oligospermia and azoospermia. 7. clin. Endocr. Metab. 32, 410-416. 
SANTEN, R.J. (1974) Control of LH secretion in man. Evidence of different mechanisms of action of testosterone and oestradiol. Proc. A. Meeting, Endocrine Society, Abstract No. 4.

Schally, A.V., Arimura, A., Kastin, A.J., Matsuo, H., Baba, Y., Redding, T.V., Nair, R.M.G. \& DEBELJuK, L. (1971) Gonadotrophin releasing hormone one polypeptide regulates secretion of luteinising and follicle stimulating hormones. Science, $\mathcal{N} . \Upsilon .173,1036-1038$.

Setchell, B.P. \& Sirinathsinghi, D.J. (1972) Antigonadotrophic activity in rete testis fluid, a possible 'inhibin'. F. Endocr. 53, ix-xi.

Sherins, R.J. \& Loriaux, D.L. (1973) Studies on the role of sex steroids in the feedback control of FSH concentrations in men. 7. clin. Endocr. Metab. 36, 886-893.

Steinberger, E. \& Chowdhury, M. (1974) Control of pituitary FSH in male rats. Acta endocr., Copenh. 76, 235-241.

Stewart-Bentley, M., Odell, W. \& Horton, R. (1974) The feedback control of luteinising hormone in normal adult men. $\mathcal{F}$. clin. Endocr. Metab. 38, 545-553.

SWERdLOFf, R.S. \& Odell, W.D. (1968) Some aspects of the control of secretion in LH and FSH in humans. In Gonadotropins, pp. 155-162. Ed. E. Rosemberg. Geron X, Los Altos, California.

SWERDLOFF, R.S., WALSH, P.C. \& OdeLl, W.D. (1972) Control of LH and FSH secretion in the male: evidence that aromatization of androgens to oestradiol is not required for the inhibition of gonadotrophin secretion. Steroids 20, 13-22.

van Theil, D.H., Sherins, R.J., Myers, G.H. \& de Vita, V.T. (1972) Evidence for a specific seminiferous tubular factor affecting follicle stimulating hormone secretion in man. $\mathcal{F}$. clin. Invest. 51, 1009-1019

von zur Muhlen, A. \& Kobberling, J. (1973) Effect of testosterone on the LH and FSH release induced by $\mathrm{LH}$ releasing factor (LRF) in normal men. Horm. Metab. Res. 5, 266-270. 